\title{
PENGARUH TERAPI PSIKORELIGIUS: MEMBACA $A L$ FATIHAH TERHADAP SKOR HALUSINASI PASIEN SKIZOFRENIA
}

\author{
Sri Mardiati ${ }^{1}$, Veny Elita ${ }^{2}$, Febriana Sabrian ${ }^{3}$ \\ Program Studi Ilmu Keperawatan Universitas Riau Jalan Pattimura No 9 Gedung G Pekanbaru Riau \\ Kode Pos 28131 Indonesia \\ Telepon 081276449090 email veny.elita@gmail.com
}

\begin{abstract}
Abstrak
Skizofrenia merupakan salah satu gangguan jiwa berat yang ditandai dengan distorsi dalam pemikiran, persepsi, emosi, bahasa, kesadaran diri dan pengalaman umum termasuk mendengar suara-suara atau yang disebut dengan halusinasi. Pengontrolan halusinasi bisa dilakukan dengan terapi psikoreligius: membaca $A l$ Fatihah. Penelitian ini bertujuan untuk mengetahui pengaruh terapi psikoreligius: membaca Al Fatihah terhadap skor halusinasi pasien skizofrenia. Penelitian ini menggunakan desain quasy experiment dengan pendekatan pretest-posttest design with control group. Penelitian dilakukan di Rumah Sakit Jiwa (RSJ) Tampan. Jumlah sampel sebanyak 34 responden yang diambil sesuai kritetria inklusi dan menggunakan teknik stratified random sampling. Responden dibagi menjadi 17 reponden kelompok eksperimen dan 17 responden kelompok kontrol. Alat ukur yang digunakan adalah kuesioner dan lembar observasi tanda dan gejala halusinasi. Analisa yang digunakan adalah analisa univariat dan bivariat untuk mengetahui distribusi frekuensi dan pengaruh terapi dengan menggunakan uji Wilcoxon dan Man-Whitney. Hasil penelitian ini menunjukkan adanya penurunan nilai median pretest dan posttest setelah diberikan terapi psikoreligius: membaca Al fatihah yaitu dari 38,00 menjadi 17,00, sehingga dapat disimpulkan bahwa ada pengaruh terapi psikoreligius: membaca Al Fatihah terhadap skor halusinasi pasien skizofrenia dengan $p$-value $(0,019)<\alpha$ $(0,05)$. Berdasarkan hasil penelitian ini disarankan kepada perawat jiwa, keluarga dan pasien agar dapat mempraktikkan terapi ini dalam penetalaksanaan pasien skizofrenia dengan halusinasi.
\end{abstract}

Kata kunci: Al Fatihah, Psikoreligius, Skor Halusinasi

\begin{abstract}
Schizophrenia is one of the major mental disorders characterized by distortions in thought, perception, emotion, language, self-awareness and general experience including hearing voices or being called hallucinations. Hallucination controlling could be done by psychoreligious therapy: reciting Al Fatihah. This research is aimed to determine influence of psychoreligious therapy: reciting Al Fatihah towards halusination score of Schizophrenia patients. This research used quasy-experiment design with pretestposttest design with control group approach. The research was conducted in Tampan Mental Hospital (RSJ Tampan). The samples of this research were 34 respondents taken from inclusion criteria based and stratified random sampling technique. The Respondents were divided into two groups: 17 respondents in experiment group and 17 respondents in control group. Measuring instruments used were questionnaire and hallucination signs and symptoms observation checklist. Univariate and bivariate analyses were used to know the distribution of frequency and therapy influence by using Wilcoxon dan Man-Whitney test. The result of the research shows that there is a decrease pretest and posttest median after psychoreligious therapy: reciting Al Fatihah from 38.00 to 17.00, so it can be concluded that Psychoreligious therapy: Reciting Al Fatihah influence the halusination score of schizophrenic patients with p-value $(0,019)<\alpha$ (0,05). Based on the result of this study, It is recommended to nurses, family and patients to practice this therapy in the treatment of schizophrenic patients with hallucinations.
\end{abstract}

Keywords : Al Fatihah,hallucination score, psychoreligious

\section{PENDAHULUAN}

Skizofrenia merupakan salah satu gangguan jiwa berat. Gangguan jiwa berat merupakan gangguan jiwa yang ditandai dengan terganggunya kemampuan menilai realitas atau tilikan (insight) yang buruk. Gangguan jiwa berat ini akan disertai dengan gejala berupa halusinasi, ilusi, waham, 
Sri Mardiati ${ }^{1}$, Veny Elita ${ }^{2}$, Febriana Sabrian $^{3}$,Pengaruh Terapi Psikoreligius: Membaca $A l$ Fatihah Terhadap Skor Halusinasi Pasien Skizofrenia

gangguan proses pikir, kemampuan berpikir, serta tingkah laku aneh seperti agresivitas atau katatonik (Kementerian Kesehatan Republik Indonesia, 2013).

Thong (2011) mengatakan bahwa skizofrenia merupakan salah satu gangguan jiwa berat yang menjadi masalah kesehatan di negara-negara berkembang dan maju. Skizofreniaadalah gangguan psikotik yang ditandai dengan gangguan utama dalam pikiran, dimana berbagai pemikiran tidak saling berhubungan secara logis, terjadinya kekeliruan persepsi dan perhatian, afek yang datar, tidak sesuai dan berbagai gangguan aktifitas motorik yang aneh (Davison, Naele \& Kring, 2006). Skizofrenia ditandai dengan distorsi dalam pemikiran, persepsi, emosi, bahasa, kesadaran diri dan pengalaman umum termasuk mendengar suara-suara atau yang disebut dengan halusinasi (WHO, 2016).Skizofrenia dialami oleh lebih dari 21 juta orang diseluruh dunia dengan kejadian setiap tahunnya terjadi pada $15-20$ per 100.000 individu. Prevalensi skizofrenia di Indonesia sebesar 1,7 per mil atau sekitar 400.000 orangdengan kejadian di Riau adalah sebanyak 0,9\% (Kementerian Kesehatan Republik Indonesia, 2013).

Hasil dari sepuluh besar diagnosa penyakit rawat inap bulan Januari sampai Desember 2016 di Rumah Sakit Jiwa (RSJ) Tampan Provinsi Riaudidapatkan data bahwa jumlah pasien skizofrenia sebanyak 958 orang dan 565 orang pasien diantaranya mengalami skizofrenia paranoid (Rekam medis RSJ Tampan, 2017). Salah satu tanda dan gejala yang muncul pada pasien skizofreniaadalah halusinasi. Halusinasi merupakan masalah gangguan jiwa terbanyak di ruang rawat inap yang ada di RSJ Tampan pada tahun 2016.

Stuart (2012) mendefinisikan halusinasi sebagai distorsi persepsi palsu yang terjadi pada respon neurobiology yang maladaptive.

Penatalaksanaan yang diberikan kepada pasien halusinasi untuk meminimalkan komplikasi atau dampak dari halusinasi sangat beragam. Penatalaksanaan ini bisa berupa terapi farmakologi, Electro Convulsive Therapy (ECT), dan terapi non farmakologi. Terapi farmakologis berupa pengobatan antipsikotik sedangkan terapi nonfarmakologis lebih mengarah kepada terapi modalitas (Viebeck, 2008).

Terapi modalitas adalah terapi kombinasi dalam keperawatan jiwa, berupa pemberian praktek lanjutan oleh perawat jiwa untuk melaksanakan terapi yang digunakan oleh pasien gangguan jiwa (Videbeck, 2008). Salah satu jenis terapi modalitas yang efektif untuk mengurangi gejala halusinasi adalah psikoterapi agama atau terapi psikoreligius (Hawari, 2010) seperti sholat, dzikir, membaca ayat Al-Quran atau mendengarkan murrotal bagi pasien yang beragama Islam.

Menurut beberapa ahli ilmu jiwa, terapi psikoreligius sangat dianjurkan. Hal ini sesuai dengan penelitian yang dilakukan oleh Setyabudi (2012) yang menyebutkan bahwa 
terapi Dzikir berpengaruh terhadap ketenangan jiwa dan dapat menurunkan stres. Sedangkan menurut Al-qadhi (2010) dengan menggunakan Al-Qur'an sebagai media relaksasi daya tahan tubuh dapat dipengaruhi sehingga mampu melawan penyakit dan membantu dalam proses penyembuhan.

$$
\text { Membaca Al-Qur'an dapat }
$$
mendatangkan kesembuhan (Wiradisuria, 2016).Mengingat Allah akan membuat tubuh rileks dengan cara mengaktifkan kerja system saraf parasimpatik dan menekan kerja system saraf simpatik. Hal ini akan membuat keseimbangan antara kerja dari kedua system saraf otonom tersebut sehingga mempengaruhi kondisi tubuh. Sistem kimia tubuh akan diperbaiki sehingga tekanan darah akan menurun, pernafasan jadi lebih tenang dan teratur, metabolisme menurun, memperlambat denyut jantung, denyut nadi, dan mempengaruhi aktivitas otak seperti mengalihkan perhatian dari rasa takut, cemas, tegang (Maimunah,2011).

Penelitian yang dilakukan oleh Fanada (2012) tentang penerapan terapi psikoreligius mendapatkan kesimpulan bahwa dengan melakukan kegiatan shalat dapat membantu menurunkan tingkat stress pada pasien halusinasi. Penelitian lain yang dilakukan oleh Hidayati (2014) tentang pengaruh terapi religius zikir menyatakan bahwa kemampuan mengontrol halusinasi pendengaran pasien meningkat setelah dilakukan terapi zikir.
Penelitian Sari (2016) tentang efektifitas mendengarkan murottal Al-Quran mendapatkan hasil bahwa murottal Al-Quran dengan surah Ar Rahman efektif dalam menurunkan skor halusinasi pasien. Selain surah Ar Rahman surah lain yang sering digunakan untuk terapi dalam kesehatan adalah surah Al Mulk, Al Falaq, AL Ikhlas, An Nas, Al Baqarah, dan Al Fatihah.Berdasarkan penelitian yang dilakukan oleh Julianto dan Subandi (2015) didapatkan hasil bahwa membaca $A l$ Fatihah dapat menurunkan depresi dengan menurunkan produksi hormon kortisol yang dipengaruhi oleh thalamus melalui coliculus superior dan coliculus inferior dan hipothalamus dengan merangsang sistem endokrin.

Surah Al Fatihah memiliki kedudukan yang tinggi dengan sebutan Ummul Kitab yang artinya induk dari seluruh Al-Qur'an. Surah Al Fatihah ini terdiri dari 7 ayat dan merupakan surah yang popular dan paling dihafal oleh umat muslim (Ridha, 2007). Surah Al Fatihah merupakan obat dari segala penyakit dan Rasulullah Saw. Telah mencontohkan berbagai macam pengobatan yang bisa dilakukan dengan surah Al Fatihah (Alcaff, 2014).Membaca surah Al Fatihah sebanyak 70 kali mampu menyembuhkan tremor atau biasa disebut gemetaran (Pedak, 2009).

Hasil wawancara yang telah dilakukan penelitipada tanggal 6 dan 10 Maret 2017 terhadap perawat yang bekerja di Ruang 
Sri Mardiati ${ }^{1}$, Veny Elita ${ }^{2}$, Febriana Sabrian $^{3}$,Pengaruh Terapi Psikoreligius: Membaca $A l$ Fatihah Terhadap Skor Halusinasi Pasien Skizofrenia

Kuantan RSJ Tampan, mendapatkan informasi bahwa beberapa asuhan keperawatan yang pernah diberikan pada pasien halusinasi adalah mengidentifikasi halusinasi, cara mengontrol halusinasi, terapi aktivitas kelompok: stimulasi persepsi sensori halusinasi, kegiatan kerohanian (ceramah agama), senam bersama, terapi Murottal Al-Qur'an dant terapi zikir AlMa'tsurat, adapun terapi membaca surat AlFatihah belum pernah dilakukan. Selanjutnya, berdasarkan hasil wawancara yang dilakukan terhadap pasien didapatkan informasi bahwa lebih banyak pasien yang hafal surah Al fatihah dari pada surah-surah pendek lainnya didalam Al-Qur'an.

Berdasarkan fenomenatersebut, maka peneliti tertarik untuk melakukan penelitian dengan judul Pengaruh Terapi psikoreligius: membaca Al Fatihah terhadap tingkat halusinasi pada pasien skizofrenia.

\section{METODOLOGI PENELITIAN}

Penelitian ini dilaksanakan di ruang rawat inap Sebayang, Kampar, Kuantan, Siak dan Indragiri Rumah Sakit Jiwa Tampan Provinsi Riau, yang dimulai dari bulan Februari sampai bulan Juli 2017. Penelitian ini menggunakan desain quasy exsperimental dengan pendekatan pretest-posttest design with control group.

Populasi dalam penelitian ini adalah pasien skizofrenia dengan diagnosa keperawatan halusinasi diRumah Sakit Jiwa Tampan Provinsi Riau dengan jumlah 218 pada bulan Februari tahun 2017. Pengambilan sampel menggunakan teknik stratified random sampling. Sampel berjumlah 34 orang pasien.

Alat pengumpul data yang digunakan yaitu kuesionerserta lembar observasiterkait tanda dan gejala dari halusinasi yang diambil dari Sudiatmika (2011).

Analisa data menggunakan analisa univariat dan analisa bivariat dengan menggunakan uji alternatif yaitu Wilcoxon dan Mann-Whitney.

\section{HASIL PENELITIAN}

\section{Analisa Univariat}

Tabel 1

Distribusi Karakteristik Responden

\begin{tabular}{|c|c|c|}
\hline $\begin{array}{c}\text { Karakteristik } \\
\text { Responden }\end{array}$ & Jumlah & $\begin{array}{c}\text { Persentase } \\
(\%)\end{array}$ \\
\hline \multicolumn{3}{|l|}{ Umur } \\
\hline Remaja akhir (17-25) & 11 & 32,4 \\
\hline Dewasa awal (26-35) & 9 & 26,5 \\
\hline Dewasa akhir (36-45) & 9 & 26,5 \\
\hline Lansia awal (46-55) & 4 & 11,8 \\
\hline Manula $(>65)$ & 1 & 2,9 \\
\hline Total & 34 & 100 \\
\hline \multicolumn{3}{|l|}{ Jenis Kelamin } \\
\hline Laki-laki & 25 & 73,5 \\
\hline Perempuan & 9 & 26,5 \\
\hline Total & 34 & 100 \\
\hline \multicolumn{3}{|l|}{ Pendidikan Terakhir } \\
\hline Tidak Sekolah & 3 & 8,8 \\
\hline SD & 15 & 44,1 \\
\hline SMP & 1 & 2,9 \\
\hline SMA & 14 & 41,2 \\
\hline Perguruan Tinggi & 1 & 2,9 \\
\hline Total & 34 & 100 \\
\hline \multicolumn{3}{|l|}{ Status Pekerjaan } \\
\hline Mahasiswa/Pelajar & 2 & 5,9 \\
\hline PNS & 2 & 5,9 \\
\hline Wiraswasta & 8 & 23,5 \\
\hline Petani & 5 & 14,7 \\
\hline Buruh & 5 & 14,7 \\
\hline Tidak Bekerja & 12 & 35,3 \\
\hline Total & 34 & 100 \\
\hline \multicolumn{3}{|l|}{ Status Pernikahan } \\
\hline Menikah & 7 & 20,6 \\
\hline Belum Menikah & 24 & 70,6 \\
\hline Bercerai & 3 & 8,8 \\
\hline
\end{tabular}




\begin{tabular}{lcc}
\hline Total & 34 & 100 \\
\hline Lama Dirawat & & \\
$<6$ bulan & 31 & 91,2 \\
$>6$ bulan & 3 & 8,8 \\
\hline Total & 34 & 100 \\
\hline
\end{tabular}

Tabel 1 menunjukkan bahwa mayoritas responden pada kelompok eksperimen dan kontrol berada pada rentang usia remaja akhir (17-25) sebanyak 11 orang (32,4\%) dengan mayoritas jenis kelamin laki-laki sebanyak 25 orang $(73,5 \%)$. Sebagian besar responden memiliki status pendidikan terakhir SD yaitu sebanyak 15 orang $(44,1 \%)$ dengan status pekerjaan mayoritas tidak bekerja sebanyak 12 orang $(35,3 \%)$. Status pernikahan mayoritas dari responden adalah belum menikah yaitu sebanyak 24 orang $(70,6 \%)$ dengan mayoritas lama dirawat $<6$ bulan yaitu sebanyak 31 orang $(91,2 \%)$.

\section{Analisa Bivariat}

Tabel 2

Uji Normalitas Data Kelompok Eksperimen dan Kontrol

\begin{tabular}{lllc}
\hline \multicolumn{2}{c}{ Kelompok } & $\mathrm{N}$ & $\mathrm{P}$ value \\
\hline \multirow{2}{*}{ Eksperimen } & Pretest & 17 & 0,276 \\
\cline { 2 - 4 } & Posttest & 17 & 0,000 \\
\hline \multirow{2}{*}{ Kontrol } & Pretest & 17 & 0,866 \\
\cline { 2 - 4 } & Posttest & 17 & 0,005 \\
\hline
\end{tabular}

Tabel 2 menunjukkan bahwa dariuji normalitas data yang menggunakan uji Shapiro-Wilk didapatkan hasil pada kelompok eksperimen pretestdan posttestdata terdistribusi tidak normal dengan $p$ valueposttest $(0,000)<\alpha(0,05)$ dan pada kelompok kontrol posttest dengan $p$ value $(0,005)<\alpha(0,05)$.

\section{Tabel 3}

Uji Homogenitas Skor Halusinasi Pretest Kelompok Eksperimen dan Kelompok Kontrol

\begin{tabular}{llll}
\hline & Median & SD & p value \\
\cline { 1 - 3 } Kelompok Eksperimen & 38,00 & 6,936 & 0,619 \\
\cline { 1 - 3 } Kelompok Kontrol & 35,00 & 8,913 & \\
\hline
\end{tabular}

Tabel 3 menunjukkan bahwa dari uji statistik didapatkan nilai median sebelum dilakukan terapi (pretest) kelompok eksperimen adalah 38,00 dengan standar deviasi 6,939 dan median kelompok kontrol adalah 35,00 dengan standar deviasi 8,913. Hasil analisa didapatkan nilai $p$ value $(0,619)>$ $\alpha \quad(0,05)$, maka skor halusinasi pretest kelompok eksperimen dan kelompok kontrol adalah homogen.

Tabel 4

Perbedaan Skor Halusinasi Pretest dan Posttest pada Kelompok Eksperimen dan Kontrol

\begin{tabular}{|c|c|c|c|c|c|}
\hline Variabel & $\mathrm{N}$ & Median & $\begin{array}{l}\text { Perbedaan } \\
\text { Median }\end{array}$ & SD & $\begin{array}{l}\mathrm{p} \\
\text { value }\end{array}$ \\
\hline $\begin{array}{l}\text { Kelompok } \\
\text { Eksperimen }\end{array}$ & 17 & & & & \\
\hline Pretest & & 38,00 & & 6,936 & 0,000 \\
\hline Posttest & & 17,00 & 21,00 & 3,572 & \\
\hline $\begin{array}{l}\text { Kelompok } \\
\text { Kontrol }\end{array}$ & 17 & & & & \\
\hline Pretest & & 35,00 & & 8,913 & 0,030 \\
\hline Posttest & & 25,00 & 10,00 & 13,62 & \\
\hline
\end{tabular}

Tabel 4 kelompok eksperimen yang dilakukan menggunakan uji Wilcoxon didapatkan selisih median skor halusinasi pretest dan posttest pada kelompok eksperimen adalah 21,00. Hasil analisa data diperoleh $p$ value $(0,000)<\alpha(0,05)$, maka 
Sri Mardiati ${ }^{1}$, Veny Elita ${ }^{2}$, Febriana Sabrian $^{3}$,Pengaruh Terapi Psikoreligius: Membaca $A l$ Fatihah Terhadap Skor Halusinasi Pasien Skizofrenia

dapat disimpulkan ada perbedaan median skor halusinasi yang signifikan sebelum dan sesudah diberikan terapi psikoreligius: membaca Al Fatihah pada kelompok eksperimen.

Uji statistik untuk kelompok kontrol yaitu uji Wilcoxonmendapatkan selisih skor halusinasi pretest dan posttest adalah 10,00. Hasil analisa data mendapatkan $p$ value $(0,030)<\alpha(0,05)$, maka dapat disimpulkan ada perbedaan antara median skor halusinasi tanpa pemberian terapi psikoreligius: membaca $A l$ Fatihah pada kelompok kontrol namun selisih angka pada kelompok kontrol tidak sesignifikan pada kelompok eksperimen.

\section{Tabel 5}

Perbedaan Nilai Posttest Skor Halusinasi pada Kelompok Eksperimen yang diberikan Terapi dengan Kelompok tanpa Pemberian Terapi

\begin{tabular}{|c|c|c|c|c|}
\hline Variabel & Median & $\begin{array}{l}\text { Perbedaan } \\
\text { Median }\end{array}$ & $S D$ & $\begin{array}{l}p \\
\text { value }\end{array}$ \\
\hline $\begin{array}{l}\text { Kelompok } \\
\text { Eksperimen }\end{array}$ & 17,00 & 8,00 & 3,572 & 0,019 \\
\hline $\begin{array}{l}\text { Kelompok } \\
\text { Kontrol }\end{array}$ & 25,00 & & 13,627 & \\
\hline
\end{tabular}

Tabel 5 menunjukkan bahwa dari uji Mann-Whitney didapatkan hasil median skor halusinasi posttest pada kelompok eksperimen adalah 17,00 sedangkan pada kelompok kontrol nilai medianhalusinasi posttest adalah 25,00 dengan selisih skor halusinasi yaitu sebanyak 8,00. Hasil uji statistik diperoleh $p$ value $(0,019)<\alpha(0,05)$, maka dapat disimpulkan ada perbedaan yang bermakna skor halusinasi antara kelompok eksperimen yang mendapatkan terapi psikoreligius: membaca $A l$ Fatihah dengan kelompok kontrol yang tidak mendapatkan terapi psikoreligius: membaca Al Fatihah. Artinya terdapat pengaruh terapi psikoreligius: membaca Al Fatihah terhadap skor halusinasi pasien skizofrenia.

\section{PEMBAHASAN}

\section{Analisa Univariat}

\section{Umur}

Berdasarkan penelitian yang telah dilakukan diketahui mayoritas umur responden berada pada tingkat remaja akhir dengan rentang 17-25 tahun yang berjumlah11 orang $(32,4 \%)$. Pada rentang usia ini individu mampu melakukan interaksi yang akrab dengan orang lain terutama lawan jenis dan mempunyai pekerjaan. Kegagalan dalam interaksi dan pekerjaan akan membuat individu menjauhi pergaulan dan merasa kesepian kemudian menyendiri (Keliat, Helena \& Farida, 2013).

Elvira (2015) menyatakan bahwa skizofrenia muncul pada usia remaja akhir atau dewasa muda dengan rentang usia 15-25 pada laki-laki dan 25-35 pada perempuan. Di usia ini individu akan mudah mengalami ketidakmampuan dalam mengatasi masalah sehingga akan mudah menyebabkan gangguan emosional.

\section{Jenis kelamin}

Hasil penelitian menunjukkan sebanyak 25 orang responden berjenis kelamin laki-laki. 
Prevalensi skizofrenia pada laki-laki dan perempuan setara, namun perbedaan terletak pada awitan dan perjalanan penyakitnya. Awitan pada laki-laki terjadi lebih dini dibandingkan pada perempuan. Lebih dari separuh pasien skizofrenia yang dirawat adalah laki-laki namun hanya sepertiga pasien skizofrenia perempuan yang dirawat di rumah sakit psikiatri (Sadock \& Sadock, 2010).

Sejumlah studi mengindikasikan bahwa laki-laki lebih cenderung mengalami hendaya (kemballinya gejala skizofrenia) akibat gejala negatif dari pada perempuan. Perempuan cenderung memiliki kemampuan fungsi sosial yang lebih baik dari laki-laki sebelum awitan penyakit. Secara umum hasil akhir pasien skizofrenia perempuan lebih baik dibandingkan hasil akhir pasien skizofrenia laki-laki (Sadock \& Sadock, 2010). Hal ini terjadi karena pasien yang berjenis kelamin perempuan lebih patuh minum obat dari pada laki-laki (Novitayani, 2016).

Kejadian gangguan jiwa berat pada perempuan lebih ringan dibanding laki-laki. Sedangkan untuk gangguan jiwa ringan dua kali lebih banyak diderita oleh perempuan dari pada laki-laki, hal ini dipengaruhi oleh kondisi sosial ekonomi.

\section{Pendidikan}

Hasil penelitian menunjukkan bahwa pendidikan mayoritas responden adalah tamat SD yaitu 15 orang (44.1\%). Hal ini disebabkan oleh kondisi pasien yang mengalami gangguan dalam pikiran dan pembicaraan, gangguan dalam isi pikiran, gangguan dalam bentuk pikiran, gangguan gerakan mata, gangguan persepsi, dan gangguan emosi (Nevid, Rathus, \& Greene, 2005), sehingga keadaan pasien ini akan mengurangi konsentrasi dalam belajar dan mempengaruhi kemampuan individu dalam menerima dan mengolah informasi.

Tingkat pendidikan dapat mempengaruhi kemampuan individu dalam menerima informasi dan mengolahnya. Tingkat pendidikan yang rendah akan memperoleh pengetahuan atau informasi yang lebih sedikit daripada individu yang berpendidikan tinggi. Hal tersebut akan mempengaruhi mekanisme koping dan pengendalian diri dalam menghadapi suatu masalah (Mayasari, 2016).

\section{Status Pekerjaan}

Berdasarkan penelitian yang telah dilakukan didapatkan informasi bahwa sebelum dirawat di RSJ Tampan mayoritas responden memiliki status pekejaan tidak bekerja yaitu 12 orang $(35,3 \%)$. Status pekerjaan termasuk kedalam faktor sosial kultural yang dapat mempengaruhi perilaku manusia (Stuart \& Laraia, 2005).

Faktor sosial kultural yang dapat mempengaruhi perilaku manusia yaitu usia, jenis kelamin, pendidikan, penghasilan, pekerjaan, posisi sosial, latar belakang budaya, nilai dan pengalaman sosial individu. Semua faktor ini dapat mempengaruhi kualitas kesehatan jiwa individu sehingga kemampuan individu dalam beradaptasi harus ditingkatkan dalam menghadapi situasi tersebut agar 
Sri Mardiati ${ }^{1}$, Veny Elita ${ }^{2}$, Febriana Sabrian $^{3}$,Pengaruh Terapi Psikoreligius: Membaca $A l$ Fatihah Terhadap Skor Halusinasi Pasien Skizofrenia

individu tidak jatuh pada skizofrenia (Damayanti, 2014).

\section{Status Pernikahan}

Berdasarkan penelitian yang dilakukan didapatkan karakteristik status pernikahan responden terbanyak adalah 24 orang $(70,6 \%)$ yaitu belum menikah. Stigma negatif yang dialami oleh penderita skizofrenia mempersulit penderita skizofrenia untuk memperoleh pasangan hidup (Loganathan \& Murthy, 2008).

Hasil penelitian ini sama dengan hasil penelitian Mayasari (2016) yang juga melakukan penelitian pada pasien skizofrenia dengan halusinasi didapatkan responden yang belum menikah adalah sebanyak 17 orang $(56,7 \%)$. Penelitian lain juga menyebutkan bahwa pasien skizofrenia yang berjenis kelamin laki-laki dapat mengalami disfungsi seksual sebagai akibat dari farmakoterapi antipsikotik olanzapine dan risperidone. Obat antipsikotik risperidone dapat membuat terjadinya disfungsi organ seksual, sedangkan antipsikotik olanzapine dapat menyebabkan terjadinya penurunan libido, masalah ejakulasi dan disfungsi erektil (Olfson, Uttaro, Carson \& Tafesse, 2005).

\section{Lama Dirawat}

Berdasarkan hasil penelitian diperoleh hasil responden terbanyak dirawat kurang dari 6 bulan yaitu 31 orang dan 3 orang responden yang dirawat lebih dari 6 bulan. Berdasarkan penelitian yang dilakukan oleh Wahyuni, Yuliet dan Elita (2012) didapatkan informasi bahwa mayoritas lama rawat pasien di RSJ Tampan adalah selama 17-109 hari dengan angka $61,8 \%$. Hasil analisis dari penelitian tersebut didapatkan nilai $p$ value $(0,158)>\alpha$ $(0,05)$ dengan kesimpulan bahwa tidak ada hubungan yang signifikan antara lama hari rawat dengan kemampuan pasien dalam mengontrol halusinasi.

Kemampuan pasien dalam mengontrol halusinasi sangat tergantung pada penatalaksanaan yang diberikan oleh tenaga kesehatan kepada pasien. Danardi (2007) menyebutkan bahwa kualitas pelayanan kesehatan sangat mempengaruhi lama hari rawat pasien. Semakin baik kualitas pelayanan kesehatan yang diberikan maka semakin cepat masa rawatnya.

\section{Analisa Bivariat}

1. Skor halusinasi pada kelompok eksperimen dan kelompok kontrol sebelum diberikan terapi psikoreligius: membaca Al Fatihah

Hasil uji homogenitas pada kelompok eksperimen dan kelompok kontrol sebelum diberikan terapi psikoreligius: membaca $A l$ Fatihah (pretest) adalah $p$ value $(0,619)>\alpha$ $(0,05)$ yang berartikedua kelompok tersebut homogen, hal ini berarti data dari kedua kelompok ini memiliki varians yang sama. Perbandingan skor halusinasi pasien skizofrenia pada kelompok eksperimen sebelum dan sesudah diberikan terapi psikoreligius: membaca $\mathrm{Al}$ Fatihah 
Nilai pretest dan posttest pada kelompok eksperimen terjadi penurunan nilai median yang signifikan yaitu dari 38,00 menjadi 17,00 perubahan sebesar 21,00 poin dengan $p$ value $(0,000)<\alpha(0,05)$. Hal ini dapat disebabkan oleh membaca Al Fatihah yang dilakukan selama satu minggu sebanyak 6 kali yang dibacakan dengan tempo yang lambat (<60 ketukan/menit) dapat mengatur irama detak jantung dan mengeluarkan endorphin sehingga membuat kenyamanan dan ketenangan. Kahel (2010) mengatakan bahwa membaca dan mendengarkan ayat Al Qur'an akan menstabilkan getaran neuron sehingga bisa melakukan fungsinya dengan baik. Ilmu kedokteran telah banyak membuktikan bahwa Al Qur'an dengan kandungannya bermanfaat untuk pengobatan (Erita \& Suharsono, 2014). Seperti yang terbukti pada penelitian ini bahwa membaca Al Qur'an bermanfaat dalam penatalaksanaan halusinasi pada kelompok eksperimen.

2. Perbandingan skor halusinasi pasien skizofrenia pada kelompok kontrol sebelum dan sesudah diberikan terapi psikoreligius: membaca Al Fatihah

Nilai pretest dan posttest pada kelompok kontrol terjadi penurunan nilai median 10 poin yaitu dari 35,00 menjadi 25,00 dengan $p$ value $0,030<\alpha(0,05) . \quad$ Penurunan ini bisa disebabkan karena telah banyaknya terapiterapi modalitas lainnya yang dilakukan diruang perawatan. Dari keterangan yang disampaikan oleh pihak perawat ruangan didapatkan informasi bahwa penatalaksanaan yang telah diberikan kepada pasien di RSJ Tampan adalah mengidentifikasi halusinasi, cara mengontrol halusinasi, terapi aktivitas kelompok: stimulasi persepsi sensori halusinasi, kegiatan kerohanian (ceramah agama), senam bersama, terapi Murottal AlQur'an dant terapi zikir Al-Ma'tsurat

Hal ini berbeda dengan penelitian yang dilakukan oleh Sari (2016) dengan judul efektifitas terapi murotal Al Qur'an terhadap skor halusinasi pendengaran didapatkan median pada kelompok Kontrol pada saat pretest adalah 32 dan posttest didapatkan sebesar 30, dengan $p$ value $0,09>\alpha(0,05)$. Pada penelitian tersebut dapat disimpulkan bahwa tidak terdapat penurunan yang signifikan antara skor halusinasi sebelum dan sesudah diberikan murotal Al-Qur'an.

3. Perbandingan skor halusinasi pasien skizofrenia pada kelompok eksperiman dan kelompok kontrol sesudah diberikan terapi psikoreligius: membaca $A l$ Fatihah

Hasil statistik menunjukkan terdapat perbedaan yang bermakna antara skor halusinasi setelah diberikan terapi psikoreligius: membaca Al Fatihah pada kelompok eksperimen dan kelompok kontrol dengan $p$ value $(0,019)<\alpha(0,05)$, terapi psikoreligius: membaca Al Fatihah efektif terhadap penurunan skor halusinasi. Penurunan skor halusinasi pada responden menunjukkan bahwa responden dengan 
Sri Mardiati ${ }^{1}$, Veny Elita ${ }^{2}$, Febriana Sabrian $^{3}$,Pengaruh Terapi Psikoreligius: Membaca $A l$ Fatihah Terhadap Skor Halusinasi Pasien Skizofrenia

pemberian terapi ini telah mampu mengontrol halusinasinya.

Menurut beberapa ahli ilmu jiwa, terapi psikoreligius sangat dianjurkan karena terapi psikoreligius ini mampu mengurangi penderitaan, meningkatkan proses adaptasi dan penyembuhan dari penyakit kejiwaan (Yosep, 2011). Salah satu terapi psikoreligius yang mampu menyembuhkan berbagai penyakit adalah dengan menggunakan Al-Qur'an (Alqadhi, 2010). Hasil kajian literatur Psychology Forum UMM (2016) menunjukkan bahwa AlQuran dapat mengobati segala bentuk penyakit jasmani dan rohani dan segala permasalahan hidup yang dialami oleh manusia tidak terbatas pada manusia yang beragama islam saja. Hal ini dikarenakan pada hakikatnya islam yang didalamnya termasuk Al-Qur'an merupakan rahmat bagi seluruh alam (Rahmatan Lill Alamin).

Terapi bacaan Al-Qur'an terbukti mampu mendatangkan ketenangan jiwa baik yang membaca maupun yang mendengarkannya (Wiradisuria, 2016). Isnawati (dalam Wiradisuria, 2016) menyebutkan bahwa membaca Al-Qur'an merupakan salah satu dari sepuluh amal shalih yang membuat tubuh selalu sehat. Al-Qur'an (Qur'an 8:2) yang artinya "sesungguhnya orang-orang yang beriman itu, hanyalah mereka yang apabila disebut nama Allah gemetarlah hati mereka dan apabila dibacakan kepada mereka ayat-ayat Nya bertambahlah keimananya(karenanya), dan kepada Tuhan lah mereka bertawakal".

Ayat tersebut menjelaskan tentang gambaran orang mukmin terhadap bacaan AlQur'an. Mendengarkan serta membaca bacaan Al-Qur'an akan berpengaruh jika dilakukan dalam keadaan yang tenang serta memperhatikan dalam arti meninggalkan kesibukan yang dapat mengganggu dari kegiatan medengarkan ataupun membaca AlQur'an.

Mengingat Allah baik dengan membaca Al-Qur'an ataupun dengan menyebut nama Allah (zikir) akan membuat tubuh rileks dengan cara mengaktifkan kerja system saraf parasimpatik dan menekan kerja system saraf simpatik. Hal ini akan membuat keseimbangan antara kerja dari kedua system saraf otonom tersebut sehingga mempengaruhi kondisi tubuh. Guyton dan Heriyati (dalam Mayasari, Elita \& Bayhaki, 2017) Sistem kimia tubuh akan diperbaiki sehingga akan meningkatkan vaskularisasi otak, meningkatkan faktor neutropik yang berperan sebagai neuroprotektif dan meningkatkan level dopamine dan serotonin. Serotonin dieksresikan oleh nucleus menuju radiks dorsalis medullaspinalis dan menuju hipotalamus Pelepasan serotonin diarea nuclei anterior dan nuclei ventromedialhipotalamus menimbulkan perasaan tenang dan nyaman.

Penelitian yang dilakukan oleh Fanada (2012) didapatkan kesimpulan bahwa dengan melakukan kegiatan shalat dapat membantu 
menurunkan tingkat stress pada pasien halusinasi. Pada penelitian lainnya yang dilakukan oleh Hidayati (2014) tentang pengaruh terapi religius zikir terhadap peningkatan kemampuan mengontrol halusinasi pada pasien halusinasi di Rumah Sakit Jiwa Daerah DR. Amino Gondohutomo Semarang menyatakan bahwa kemampuan mengontrol halusinasi pendengaran pasien meningkat setelah dilakukan terapi zikir.

Penelitian Sari, Jumaini, dan Utami (2016) tentang efektifitas mendengarkan murottal Al-Quran terhadap skor halusinasi pada pasien halusinasi pendengaran didapatkan hasil bahwa murottal Al-Quran dengan surah Ar Rahman efektif dalam menurunkan skor halusinasi pasien. Selain surah Ar Rahman surah lain yang sering digunakan untuk terapi dalam kesehatan adalah surah Al Mulk, Al Falaq, AL Ikhlas, An Nas, Al Baqarah, dan Al Fatihah.

Berdasarkan penelitian yang dilakukan oleh Julianto dan Subandi (2015) dengan judul membaca $A l$ Fatihah reflektif intuitif untuk menurunkan depresi dan meningkatkan imunitas didapatkan hasil bahwa membaca $A l$ Fatihah dapat menurunkan depresi dengan menurunkan produksi hormon kortisol. Dengan menurunnya produksi hormon ini maka akan membuat jiwa menjadi tenang sehingga tidak mengganggu keadaan homeostasis dalam diri.

Keadaan tenang akan memberikan dampak pada fisiologis tubuh seperti detak jantung yang melambat, tekanan darah menurun, suhu tubuh meningkat dan pernafasan yang dalam dan panjang (Rusdi \& Isnawati, 2009).

Bacaan Al-Qur'an secara fisik mengandung unsur suara manusia, sedangkan suara manusia merupakan instrumen penyembuhan yang menakjubkan dan alat yang paling mudah dijangkau,suara tempo yang lambat $\quad(<60 \quad$ ketukan/menit $)$ menimbulkan ketenangan dan kenyamanan (Heru, 2008). Bacaan ayat suci Al-Qur'an yang dibacakan dengan tempo yang lambat, lembut dan penuh penghayatan dapat menimbulkan suatu respon relaksasi.

Yosep (2011) mengatakan bahwa terapi religius mampu mencegah dan melindungi dari penyakit kejiwaan, mengurangi penderitaan, meningkatkan proses adaptasi. Berdasarkan keterangan diatas dapat disimpulkan bahwa terapi psikoreligius: membaca Al Fatihah dapat menurunkan skor halusinasi pada pasien skizofrenia.

\section{SIMPULAN}

Berdasarkan penelitian yang dilakukan didapatkan hasil sebagai berikut: responden berusia antara 17-69 tahun dengan mayoritas jenis kelamin laki-laki $(73,5 \%)$ dan paling banyak berpendidikan SD (44,1\%). Mayoritas status pekerjaan responden adalah tidak bekerja $(35,5 \%)$ dan status pernikahan yang paling banyak adalah belum menikah $(70,6 \%)$. 
Sri Mardiati ${ }^{1}$, Veny Elita ${ }^{2}$, Febriana Sabrian $^{3}$,Pengaruh Terapi Psikoreligius: Membaca $A l$ Fatihah Terhadap Skor Halusinasi Pasien Skizofrenia

Hasil penelitian ini juga didapatkan rata-rata lama dirawat pasien adalah $<6$ bulan $(91,2 \%)$.

Skor halusinasi pada kelompok eksperimen didapatkan nilai significancy $(p$ value) $0,019<\alpha(0,05)$, maka dapat disimpulkan bahwa Ho ditolak. Hal ini berarti ada perbedaan antara pretest dan posttest dan terjadi penurunan nilai median pretest dan posttest diberikan terapi psikoreligius: membaca Al fatihah itu dari 38,00 menjadi 17,00, dapat disimpulkan bahwa adanya penurunan skor halusinasi pada kelompok eksperimen yang telah diberikan terapi psikoreligius: membaca $\mathrm{Al}$ fatihah. Berdasarkan hasil penelitian ini dapat disimpulkan bahwa terapi psikoreligius: membaca Al Fatihah berpengaruh terhadap penurunan skor halusinasi pasien skizofrenia di RSJ Tampan Provinsi Riau.

\section{SARAN}

Berdasarkan hasil penelitian ini peneliti menyarankan agar petugas kesehatan, pasien dan keluarga pasien bisa menerapkan terapi ini dalam penatalaksanaan pasien dengan halusinasi.

\section{DAFTAR PUSTAKA}

Alcaff, M. (2014). Tafsir Populer Al-Fatihah. Bandung: Mizan.

Al-Qadhi, A. A. Y. (2010). An introduction to the sciences of the qur'aan. Diperoleh tanggal 20 Juni 2017 dari https://theauth enticbase.files.wordpress.com/2010/11/i ntroduction-sciences-of-the-quran-yasirqadhi.pdf
Al Qur'an terjemahan departemen agama. (2010). Bandung: Tiga Serangkai.

Damayanti, R., Jumaini, \& Utami, S. (2014). Efektifitas musik klasik terhadap penurunan tingkat halusinasi pada pasien halusinasi dengar di RSJ Tampan Provinsi Riau. Di peroleh tanggal 20 Juli 2017 dari http:// www.jom.unri.ac.id/index.php/JOMPSI K/article/view/3394/3291

Danardi. (2007). Asuhan keperawatan bermutu di Rumah Sakit Jiwa. Diperoleh tanggal 20 Juni 2017 dari http://persi.co.id/padav ersi.news/artikel.php.3.id

Davison, G. C., Neale, J. M., \& Kring, A. M. (2006). Psikologi abnormal. ( $9^{\text {th }}$ ed). Jakarta: PT Raja Gravindo Persada.

Elvira, S. (2015). Bahan ajar psikiatri. Jakarta: Badan Penerbit FKUI.

Erita \& Suharsono. (2014). Pengaruh membaca Al Qur'an dengan metode tahsin terhadap depresi pada lansia di Panti Sosial Tresna Werdha Unit Aboyoso Pakem Yogyakart a. Diakses tanggal 20 Juni 2017 dari http ://thesis.umy.ac.id/datapublik/t34597.pdf

Fanada, M. (2012). Perawat dalam penerapan terapi psikoreligius untuk menurunkan tingkat stres pada pasien halusinasi pendengaran $d i$ Rawat Inap Bangau Rumah Sakit Ernald $i$ Bahar Palembang. Diperoleh tanggal 2 0 Juli 2017 dari http://www.bayuasinkab .go.id>dokumens

Fitryasari, Y., R \& Nihayati, H., E. (2015). Buku ajar keperawatan kesehatan jiwa. Jakarta: Salemba Medika.

Hawari, D. (2010). Manajemen stres, cemas dan depresi. Jakarta: Balai Penerbit FKUI

Heru. (2008). Ruqyah syar'i berlandaskan kearifan lokal. Diakses tanggal 20 Juni 2017 dari http://trainermuslim.com/feed/ rss

Hidayati, W. C. (2014). Pengaruh terapi religius

zikir terhadap peningkatan kemampuan mengontrol halusinasi pendengaran pada pasien halusinasi di RSJD DR. Amino Gondohu tomo Semarang. Jurnal Keperawatan dan 
Kebidanan. Diperoleh tanggal 25 Febru ari 2017 dari http://pmb.stikestelogorejo. ac.id/ejournal/index.php/ilmukeperawata n/article/view/243

Julianto, V., \& Subandi. (2015). Membaca Al Fatihah reflektif intuitif untuk menurunk an depresi dan meningkatkan imunitas. Diperoleh pada tanggal 20 Juni 2017 dari https://journal.ugm.ac.id/jpsi/article/ view/6941

Kaheel, A. (2013). Sembuhkan sakitmu dengan Al-Qur"an. Yogyakarta: Laras Media Prima.

Keliat, B. A., Helena, N., \& Farida, P. (2013). Manajemen keperawatan Psikososial \& kader kesehatan jiwa. Jakarta: EGC.

Kementerian Kesehatan Republik Indonesia. (2013). Riset kesehatan dasar. Departem en Kesehatan Republik Indonesia. Diper oleh tanggal 25 Februari 2017. Dari http: //www.depkes.go.id/resources/download /general/Hasil\%20Riskesdas\%202013.pd $\mathrm{f}$

Kusumawati, F \& Hartono, Y. (2010). Buku ajar keperawatan jiwa. Jakarta: Salemba Medika.

Loganathan, S. \& Murthy, S. R. (2008). Experiences of stigma and discriminatio $n$ endured by people suffering from schizophrenia. Diperoleh tanggal 20 Juni 2017 dari https://www.ncbi.nlm.nih. gov/pubmed/19771306

Maimunah, A. (2011). Pengaruh relaksasi dengan dzikir untuk mengatasi kecemasa $n$ ibu hamil pertama. Diperoleh tanggal 20 Juni 2017 dari http://etd.repository.ug m.ac.id

Mayasari, E. (2017). Efektifitas terapi psikoreligius: Zikir Al Ma'tsurat terhada p skor halusinasi pendengaran pada pasien skizofrenia. Skripsi PSIK UNRI. Tidak dipublikasikan.

Nevid, J.S., Rathus, S.A., \& Greene, B. (2005). Psikologi abnormal. $\left(5^{\text {th }}\right.$ ed) (Tim Fakultas Psikologi Universitas Indonesia, Penerjemah). Jakarta: Erlangga.

Novitayani, S. (2016). Karakteristik pasien skizofrenia dengan riwayat rehospitalisa si. Diperoleh tanggal 20 juni 2017 dari ht
tp://www.jurnal.unsyiah.ac.id/INJ/article /view/6442/5279

Olfson, M., Uttaro, T., Carson, W. H., \& Tafesse, E. (2005). Male sexual dysfunct ion and quality of life in schizofrenia. Diperoleh tanggal 20 Juni 2017 dari http s://www.ncbi.nlm.nih.gov/pubmed/1576 6299

Pedak, M. (2009). Mukjizat terapi Al-Qur'an untuh hidup sukses. Jakarta: Wahyu Medika.

Rekam medis pasien. (2016). Sepuluh besar diagnosa penyakit rawat Inap Bulan Januari sampai Desember 2016 Rumah Sakit Jiwa Tampan. Pekanbaru: RSJ Tampan.

Ridha, M. R. (2007). Tafsir Al Fatihah (mene mukan hakikat ibadah). Bandung: $\mathrm{Al}$ bayan Mizan.

Sadock, B. J., \& Sadock, A. V. (2010). Kaplan \& sadock buku ajar psikiatri. (2 ${ }^{\text {th }}$ ed) (Profitasari \& Tiara Mahatmi Nisa, Penerjemah). Jakarta: EGC.

Sari, A., Jumaini, \& Utami, S (2016). Efektifitas mendengarkan murottal Alquran terhadap skor halusinasi pada pasien halusinasi pendengaran. Diperoleh tanggal 20 Juni 2017 dari https://jom.unri.ac.id/index.ph p/JOMPSIK/article/view/13097

Setyabudi, I. (2012). Pengembangan metode efektifitas dzikir untuk menurunkan stres dan afek negatif pada penderita stadium AIDS.

Diperoleh pada 20 Juni 2017 dari http://s 3.amazonaws.com/academia.edu.docum ents/45368933/zikir_stress_aids.pdf?AW SAccessKeyId=AKIAIWOWYYGZ2Y5 3UL3A\&Expires $=1501211455 \&$ Signatu re $=1 \mathrm{mCZ5KX7Pw3SkWEdk9A4qEybn}$ NE\%3D\&response content disposition $=\mathrm{i}$ nline \%3B\%20filename\%3DPENGEMB ANGAN_METODE_EFEKTIVITAS_D ZIKIR_U.pdf

Stuart, G.W., \& Laraia, M.T. (2005). Principle and practice of psychiatric nursing. Philadelphia: Elseiver Mosby.

Sudiatmika, I. K. (2011). Efektifitas cognitive behavior therapy dan rational emotive behavior therapy terhadap klien dengan perilaku kekerasan dan halusinasi di 
Sri Mardiati ${ }^{1}$, Veny Elita ${ }^{2}$, Febriana Sabrian $^{3}$,Pengaruh Terapi Psikoreligius: Membaca $A l$ Fatihah Terhadap Skor Halusinasi Pasien Skizofrenia

Rumah Sakir DR. H. Marzoeki Mahdi Bogor. Diperoleh tanggal 06 April 2017 dari http://lib.ui.ac.id/file?file=digital/202814 32 T\%20I\%20Ketut\%20Sudiatmika\%20 baru.pdf

Thong, D. (2011). Memanusiakan manusia menata jiwa membangun bangsa. Jakarta: Gramedia.

Videbeck, S. L. (2008). Buku ajar keperawatan jiwa. Jakarta: EGC.

Wahyuni, S., Yuliet, S. N., Elita, V. (2012). Hubungan lama hari rawat dengan kemampuan pasien dalam mengontrol halusinasi. Diperoleh tanggal 20 Juni 2017 dari http://download.portalgaruda.o rg/article.php?article $=32283 \&$ val $=2290$

Wiradisuria, S. (2016). Menggapai kesembuha $n$, sebuah harapan dan peluang menapa ki jalan kebahagiaan. Diperoleh tanggal 20 Juni 2017 dari https://books.google.c o.id/books?id=ZlHTDQAAQBAJ\&pg=P A69\&dq=membaca + al + quran + dan + kese mbuhan\&hl=id\&sa $=X \& v e d=0$ ahUKEwj XuLC04cfVAhUMuI8KHRX1CiUQ6A EIOjAE\#v=onepage \&q=membaca\%20al $\% 20$ quran\%20dan\%20kesembuhan $\& \mathrm{f}=\mathrm{f}$ alse

World Health Organitation. (2016). Schizophre nia. Diperoleh tanggal $20 \mathrm{M}$ aret 2017. Dari http://www.who.int/mediacentre/fac tsheets/fs397/en/

Yosep, I. (2011). Keperawatan Jiwa. Bandung : PT Revika Aditama. 